\title{
The Ocean's Vital Skin: Toward an Integrated Understanding of the Sea Surface Microlayer
}

\section{OPEN ACCESS}

Edited by:

Cecile Guieu,

Centre National de la Recherche Scientifique (CNRS), France

Reviewed by:

Sanja Frka Milosavljević, Rudjer Boskovic Institute, Croatia Darius Ceburnis,

NUI Galway, Ireland

*Correspondence: Anja Engel aenge/@geomar.de

Specialty section:

This article was submitted to Marine Biogeochemistry, a section of the journal Frontiers in Marine Science

Received: 24 February 2017 Accepted: 12 May 2017 Published: 30 May 2017

Citation:

Engel A, Bange HW, Cunliffe $M$ Burrows SM, Friedrichs G, Galgani L, Herrmann H, Hertkorn N, Johnson M, Liss PS, Quinn PK, Schartau M, Soloviev A, Stolle $C$

Upstill-Goddard RC, van Pinxteren M and Zäncker B (2017) The Ocean's

Vital Skin: Toward an Integrated Understanding of the Sea Surface Microlayer. Front. Mar. Sci. 4:165. doi: 10.3389/fmars.2017.00165

\author{
Anja Engel ${ }^{1 *}$, Hermann W. Bange ${ }^{1}$, Michael Cunliffe ${ }^{2}$, Susannah M. Burrows ${ }^{3}$, \\ Gernot Friedrichs ${ }^{4}$, Luisa Galgani ${ }^{1,5}$, Hartmut Herrmann ${ }^{6}$, Norbert Hertkorn ${ }^{7}$, \\ Martin Johnson ${ }^{8}$, Peter S. Liss ${ }^{8}$, Patricia K. Quinn ${ }^{9}$, Markus Schartau ${ }^{1}$, \\ Alexander Soloviev ${ }^{10}$, Christian Stolle ${ }^{11,12}$, Robert C. Upstill-Goddard ${ }^{13}$, \\ Manuela van Pinxteren ${ }^{6}$ and Birthe Zäncker ${ }^{1}$
}

${ }^{1}$ GEOMAR Helmholtz Centre for Ocean Research Kiel, Kiel, Germany, ${ }^{2}$ The Marine Biological Association of the United Kingdom, Plymouth, United Kingdom, ${ }^{3}$ Pacific Northwest National Laboratory (DOE), Richland, WA, United States, ${ }^{4}$ Kiel Marine Science, Institute of Physical Chemistry, Kiel University, Kiel, Germany, ${ }^{5}$ Department of Biotechnology, Chemistry and Pharmacy, University of Siena, Siena, Italy, ${ }^{6}$ Chemistry of the Atmosphere, Leibniz-Institute for Tropospheric Research, Leipzig, Germany, ${ }^{7}$ Helmholtz Zentrum München (HZ), Munich, Germany, ${ }^{8}$ School of Environmental Sciences, University of East Anglia, Norwich, United Kingdom, ${ }^{9}$ Pacific Marine Environmental Laboratory, National Oceanic and Atmospheric Administration (NOAA), Seattle, WA, United States, ${ }^{10}$ Department of Marine and Environmental Sciences, Halmos College of Natural Sciences and Oceanography, Nova Southeastern University, Fort Lauderdale, FL, United States, ${ }^{11}$ Biological Oceanography, Leibniz-Institute for Baltic Sea Research Warnemuende, Warnemuende, Germany, ${ }^{12}$ Institute for Chemistry and Biology of the Marine Environment (ICBM), Carl von Ossietzky University Oldenburg, Oldenburg, Germany, ${ }^{13}$ School of Marine Science and Technology, Newcastle University, Newcastle upon Tyne, United Kingdom

Despite the huge extent of the ocean's surface, until now relatively little attention has been paid to the sea surface microlayer (SML) as the ultimate interface where heat, momentum and mass exchange between the ocean and the atmosphere takes place. Via the SML, large-scale environmental changes in the ocean such as warming, acidification, deoxygenation, and eutrophication potentially influence cloud formation, precipitation, and the global radiation balance. Due to the deep connectivity between biological, chemical, and physical processes, studies of the SML may reveal multiple sensitivities to global and regional changes. Understanding the processes at the ocean's surface, in particular involving the SML as an important and determinant interface, could therefore provide an essential contribution to the reduction of uncertainties regarding ocean-climate feedbacks. This review identifies gaps in our current knowledge of the SML and highlights a need to develop a holistic and mechanistic understanding of the diverse biological, chemical, and physical processes occurring at the ocean-atmosphere interface. We advocate the development of strong interdisciplinary expertise and collaboration in order to bridge between ocean and atmospheric sciences. Although this will pose significant methodological challenges, such an initiative would represent a new role model for interdisciplinary research in Earth System sciences.

\section{Keywords: sea surface microlayer, air-sea exchange, neuston, aerosols, surface films, gas exchange, review}

\section{INTRODUCTION}

Surfaces and interfaces are critical zones where major physical, chemical, and biological exchanges occur. As the ocean covers 362 million $\mathrm{km}^{2}(\sim 71 \%)$ of the Earth's surface, the ocean-atmosphere interface is arguably one of the largest and most important interfaces on the planet. Every substance entering or leaving the ocean from or to the atmosphere passes through this interface, which on the 
water-side -and to a lesser extent on the air-side- shows distinct physical, chemical, and biological properties. On the water side the uppermost $1-1,000 \mu \mathrm{m}$ of this interface are referred to as the sea surface microlayer (SML) (Hunter, 1980) (Figure 1). Like a skin, the SML is expected to control the rates of exchange of energy and matter between air and sea, thereby potentially exerting both short-term and long-term impacts on various Earth system processes, including biogeochemical cycling and climate regulation (Cunliffe et al., 2013). Yet, processes occurring within the SML, as well as the associated rates of material exchange through the SML, are still poorly understood. Consequently, they are rarely represented in marine and atmospheric numerical models.

An improved understanding of the biological, chemical, and physical processes at the ocean's upper surface could provide an essential contribution to the reduction of uncertainties regarding ocean-climate feedbacks. Due to its positioning between atmosphere and ocean, the SML is the first to be exposed to climate changes including temperature, climate relevant trace gases, wind speed, and precipitation as well as to pollution by human waste, including nutrients, toxins, nanomaterials, and plastic debris.

During the past two decades the number of publications addressing the SML has more than tripled, from 15 year $^{-1}$ at the beginning of this century to $\sim 50$ year $^{-1}$ in 2016 (Web of Science, Thomson Reuters 2016). These studies shed new light on the organic and organismal constituents of the SML and emphasized its roles in air-sea gas-exchange and in the production of primary organic aerosols. Recent in-depth reviews summarize current knowledge of the SML, including aspects of its composition, key processes and overall role in the Earth system (Liss and Duce,
2005; Cunliffe et al., 2013; Law et al., 2013; Garbe et al., 2014; Carpenter and Nightingale, 2015). Conceptions of the structure of the SML and its dynamics are diverse, placing emphasis on a range of processes and spatial and temporal scales (Figure 1). The purpose of this critical review is to identify the main open questions, controversies, and challenges that inhibit our current understanding of the SML and to identify how SML studies can be better integrated into marine and climate research.

\section{WHAT IS LIFE AT THE AIR-SEA INTERFACE?}

As with other marine ecosystems, life in the SML is dominated by microorganisms, which are collectively referred to as the "neuston," whereas "plankton" describes the microscopic organisms that inhabit the underlying water column. So far, most recent studies have focused on the diversity and abundance of bacterioneuston assemblages, principally through the application of molecular ecology tools (for a review see Cunliffe et al., 2011). The consensus view is that bacterioneuston assemblages form by recruitment from the underlying bacterioplankton; however, the species composition and activity of bacterioneuston assemblages can be very different compared to those in the underlying water column (Agogue et al., 2005; Franklin et al., 2005; Obernosterer et al., 2008; Stolle et al., 2011; Taylor et al., 2014). What exactly controls bacterioneuston species diversity is at present not fully understood, but evidence from both field observations (Cunliffe et al., 2009a) and large-scale mesocosm experiments (Cunliffe et al., 2009c) suggests that the development of bacterioneuston assemblages is ecologically regulated and not random (Cunliffe et al., 2011). Possible controls

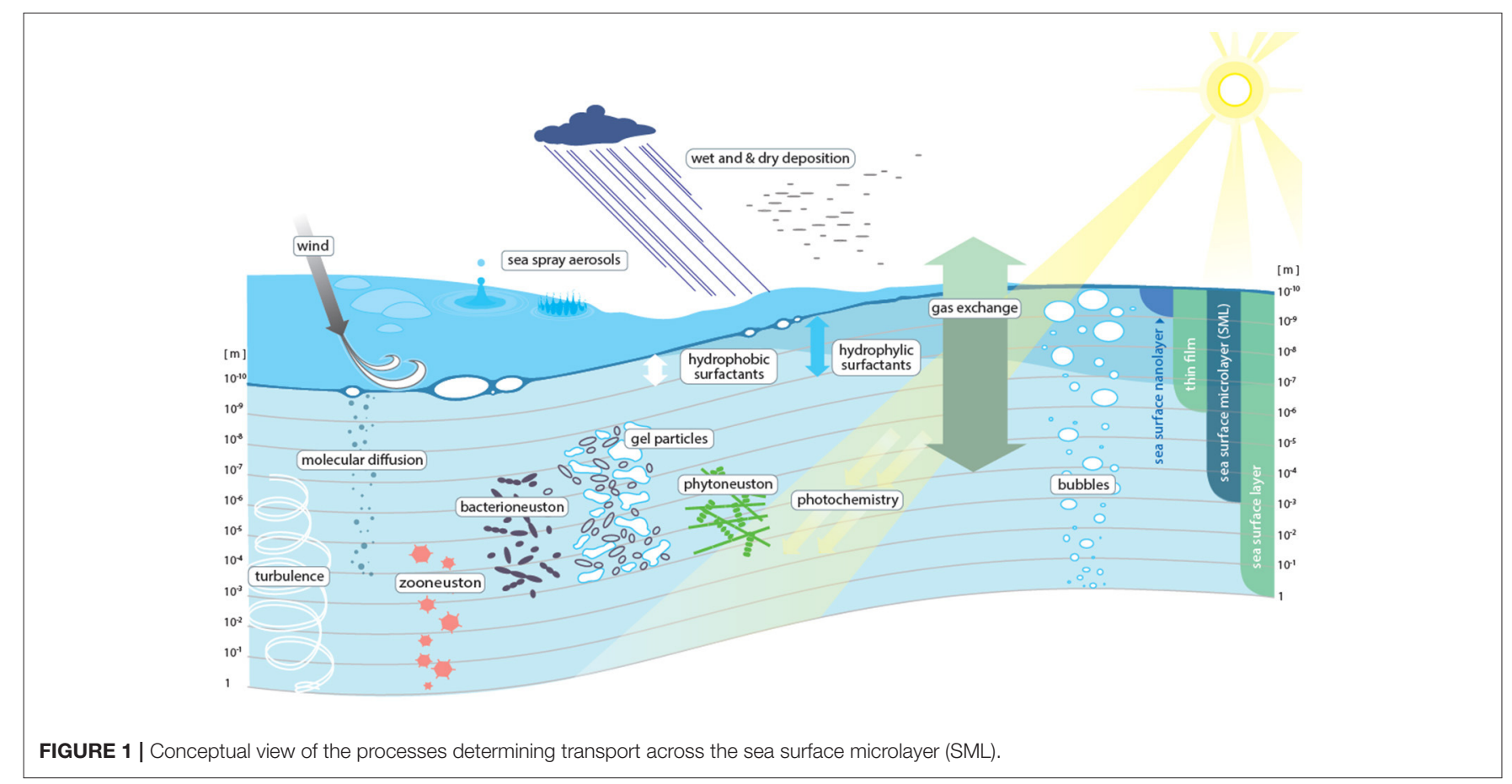


of bacterioneuston diversity and activity include the prevailing meteorological conditions, incident UV light, organic matter availability and aerosol deposition (Carlucci et al., 1985; Agogue et al., 2005; Stolle et al., 2010, 2011; Nakajima et al., 2013; Astrahan et al., 2016). It is, however, not clear whether solar and UV irradiance promote or inhibit neuston activity (Bailey et al., 1983; Carlucci et al., 1985; Santos et al., 2012).

The bacterioneuston has been shown to directly influence air-sea gas exchange by consuming and producing trace gases (e.g., $\mathrm{CO}, \mathrm{H}_{2}, \mathrm{CH}_{4}, \mathrm{~N}_{2} \mathrm{O}$ ) (Conrad and Seiler, 1988; Frost, 1999; Upstill-Goddard et al., 2003; Nakajima et al., 2013). The addition of methanotrophs in a laboratory gas exchange tank led to an enhancement of the apparent transfer velocity of $\mathrm{CH}_{4}$ by $12 \pm 10 \%$ (Upstill-Goddard et al., 2003). Later work reported bacterial growth efficiency in the SML and underlying water to be similar, but also showed higher respiration in the SML that pointed to some potential control of the air-sea exchange of $\mathrm{CO}_{2}$ and $\mathrm{O}_{2}$ by the bacterioneuston (Reinthaler et al., 2008). Through the application of functional gene probes to a range of SML environments, the metabolic potential for trace gas cycling in the SML has since been established as being widespread (Cunliffe et al., 2008, 2011). It can therefore be concluded that for some trace gases such as $\mathrm{CH}_{4}$ and $\mathrm{CO}_{2}$, the bacterioneuston is intimately involved in their cycling and that it may potentially act as either a small gas source or sink in response to the prevailing microbial and biogeochemical conditions. The bacterioneuston may also modulate the enrichment of surfactants in the SML and thus indirectly influence air-sea gas exchange, as indicated by a recent study relating SML surfactant enrichment and the occurrence of specific bacterial taxa (Kurata et al., 2016).

The second major biological component of SML ecosystems is phytoneuston, historically studied using microscopes (Hardy and Valett, 1981; Hardy, 1982), and more recently through high-throughput sequencing (Taylor and Cunliffe, 2014). Highthroughput sequencing of phytoneuston assemblages in the coastal SML of the English Channel showed that biodiversity at the interface was very different to that in the underlying water (Taylor and Cunliffe, 2014). Two major algal groups, the chrysophytes and the diatoms, were significantly enriched in the neuston, with diatom diversity in particular being distinctly different to that of planktonic diatoms. While the functional impacts of the differences between phytoneuston and phytoplankton abundance and diversity are not yet fully understood, it is believed that specific processes such as the maintenance of air-sea $\mathrm{CO}_{2}$ disequilibria could be controlled, at least in part, by the phytoneuston (Calleja et al., 2005).

Other components of SML ecosystems such as heterotrophic protists and zooneuston have also been studied, but to a lesser extent. Looking forward, the application of contemporary tools, such as high-throughput sequencing, hold great promise in revealing new insights into the biology of the SML. The recent English Channel study discussed above also showed that the diversity of neustonic fungi (myconeuston) is also distinctly different from mycoplankton diversity (Taylor and Cunliffe, 2014). Relative to other marine microbial groups, the marine fungi remain poorly understood. A recent study of the coastal mycoplankton implicated marine fungi in a range of ecosystem functions, including nutrient recycling and parasitism (Taylor and Cunliffe, 2016). Exactly what functional roles myconeuston may play at the ocean-atmosphere interface still remain to be revealed.

Marine aerosols that are formed from the SML via bubble bursting are a vector for the transfer of microbial life from the lower water column and SML into the atmosphere. Measurements of bacteria and viruses in sea spray aerosols (SSA) show large enrichments relative to both the SML $(\sim 5)$ and subsurface waters $(\sim 10)$ (Aller et al., 2005). A key factor in this process appears to be the embedding of microorganisms within the organic gel matrix that forms in the SML (discussed further below) (Aller et al., 2005). The global-scale implications for ocean-atmosphere exchange of microorganisms are profound because this process may have a major impact on the longdistance dispersal of marine microbial life. For example, phytoplankton viruses that are transported into the atmosphere from the SML can remain highly infective under prevailing meteorological conditions and can be spread across hundreds of kilometers to subsequently infect distal phytoplankton (Sharoni et al., 2015).

Organisms in the SML interact with the surface accumulation of organic matter produced by biological processes in the underlying water column (Galgani et al., 2014). Some dissolved compounds have surface active (surfactant) properties or adsorb onto floating compounds and selectively become enriched in the SML (Hunter and Liss, 1977). The accumulation of surfactants in the SML was found to be related to the occurrence of certain bacterioneuston taxa, indicating microbial contribution to surfactant production and decomposition (Kurata et al., 2016). In addition to soluble surfactants, the SML also accumulates a variety of colloidal and particulate organic matter that may serve as substrates for the bacterioneuston. Sieburth (1983) proposed the SML to be a complex hydrated "gel" of macromolecules and colloidal material.

The "gel" material has now been identified and studied in greater detail. Included in the gelatinous matrix are transparent exopolymer particles (TEP), i.e., polysaccharide-rich microgels that are produced primarily by the abiotic coagulation of phytoplankton exudates (Passow, 2002), and Coomassie stainable particles (CSP) containing proteinaceous polymers released during cell lysis and decomposition (Long and Azam, 1996). The aggregation of TEP precursors in the SML is enhanced due to the constant compression and dilation of the air-sea interface (Wurl et al., 2011), which may explain, at least in part, the gelatinous nature of the SML. Gel particles may serve as grazing protection for the phytoneuston and bacterioneuston, as has been shown for their planktonic counterparts (Passow and Alldredge, 1999; Dutz et al., 2005). In addition, TEP have been suggested to protect neuston from high irradiance (Ortega-Retuerta et al., 2009), possibly helping the neuston withstand periods of high irradiation of the SML.

Currently there is no consensus about which biogenic substances become selectively enriched in the SML, or why, and when. Many studies reported that particulate organic matter is more extensively enriched in the SML than is dissolved organic matter. Most studies report higher enrichment factors (the ratio 
between SML and subsurface concentrations) for proteinaceous compounds than for others (Henrichs and Williams, 1985; Carlucci et al., 1992; Kuznetsova and Lee, 2001, 2002; Kuznetsova et al., 2004; Reinthaler et al., 2008). Several recent studies also showed that the SML can be highly enriched in gel particles, with enrichment factors $>10$, in particular under calm wind conditions (Cunliffe et al., 2009b; Wurl et al., 2011, 2016; Galgani et al., 2014; Engel and Galgani, 2016; Thornton et al., 2016). However, in many of these studies enrichment was highly variable, with depletion of organic matter in the SML, including gels, also being observed. Clearly, understanding organic compound enrichment and microbial uptake and cycling in the SML requires an improved knowledge of: (i) the chemical nature of organic molecules; (ii) the functioning of the ecosystem below and within the SML; and (iii) the mechanisms that transport organic matter into and out of the SML.

\section{DO WE NEED TO BETTER RESOLVE THE AIR-SEA INTERFACE TO ENABLE MORE ACCURATE DESCRIPTIONS OF AIR-SEA GAS EXCHANGE?}

A classical view of the ocean's surface is that encapsulated in the surface film model, where two stagnant films (or viscous boundary layers), one at the air side and one at the water side, control the exchange of heat, momentum and gases between the ocean and the atmosphere (e.g., Liss and Slater, 1974).

More recent physical theories mechanistically connect the transfer of heat and momentum to mass flux, in particular gas flux, and distinguish between a skin or mass boundary layer of molecular diffusion about $10 \mu \mathrm{m}$ in thickness, and sub-layers, about $10^{2}-10^{3} \mu \mathrm{m}$ thick, in which strong viscous dissipation of turbulence occurs (e.g., Soloviev and Schlüssel, 1994; Jähne and Haußecker, 1998; Turney et al., 2005). Two basic dynamical model approaches are currently applied.

The first is based on a stochastic description of the instantaneous near-surface renewal of small volume elements of the fluid (Danckwerts, 1951); this is referred to as the surface renewal model. It requires estimates of the mean surface renewal time, a parameter that expresses the duration between events when surface gas/mass concentrations are homogenized to those of the underlying bulk water. Infrared thermal imaging of the sea surface can be well-explained by the renewal model (e.g., Schimpf et al., 2004), which additionally supports it as a meaningful description of air-sea gas exchange. The major challenge to its application is its ability to allow reliable estimates for the timescale of renewal events and to link these timescales to the underlying physical processes.

The second dynamical model approach is via the surface divergence model. This considers the root mean square of surface divergence of those velocity components that are tangential to the air-sea interface (McCready et al., 1986). One advantage of the divergence model is that it does not require a renewal time to be specified (Banerjee et al., 2004). Another is that mass transfer velocities can be inferred from small-scale surface images that resolve small spatial-temporal variations in horizontal velocity gradients (Turney et al., 2005). The ability of either model to simulate gas transfer strongly depends on wind conditions, the surface divergence model performing best under calm wind conditions. The successful combination of elements of surface renewal and surface divergence into a single model should improve future model predictions of air-sea gas exchange (Turney and Banerjee, 2013).

Many descriptions of air-sea gas exchange adopt the surface film model that treats the interface as a boundary for which a bulk gas transfer velocity for the water side $\left(k_{\mathrm{w}}\right)$ can be derived from wind speed, the solubility and molecular diffusivity of the gas in question, and the kinematic viscosity of seawater (e.g., Liss and Merlivat, 1986; Wanninkhof, 1992; Nightingale et al., 2000). Indeed, estimates of $k_{w}$ derived from seawater salinity, temperature and wind speed data can explain between 50 and $80 \%$ of the variability observed during tracer studies (Ho et al., 2011). However, considerable uncertainties and biases remain in these estimates, particularly under both calm and stormy wind conditions, either because the underlying mechanisms remain unresolved or, as in the case of stormy conditions, they are technically difficult to investigate (see e.g., Wanninkhof et al., 2009; Garbe et al., 2014).

As alluded to above, air-sea gas transfer is influenced by molecular diffusion (Garbe et al., 2014). Therefore, the effective value of the gas diffusivity applied in gas transfer models is an important quantity. It is well-documented from measurements of gas permeability that the gas diffusivity in various dense surface films can be quite low (Blank, 1962). Even so, the extent to which the presence of a SML including particles, gels, and high molecular weight compounds modulates diffusion effects under ambient conditions remains unclear.

Another poorly characterized descriptor of air-sea gas exchange is the importance of surfactants accumulating at the air-sea interface. Recent work in the Atlantic Ocean implies that surfactant enrichment of the SML could be a ubiquitous feature of the open ocean up to wind speeds of $\sim 13 \mathrm{~m} \mathrm{~s}^{-1}$ and possibly even higher (Sabbaghzadeh et al., 2017). This is important because surfactants have the ability to alter the hydrodynamic properties of the interface and suppress gas exchange by forming a physico-chemical barrier or by modifying aspects of sea surface hydrodynamics such as turbulent energy transfer, micro-scale wave breaking and surface renewal, and by damping small capillary waves (Frew et al., 1990; Tsai, 1996, 1998; McKenna and McGillis, 2004; Garbe et al., 2014; Pereira et al., 2016). In the SML, both insoluble (hydrophobic; dry) surfactants (e.g., fatty acids) that tend to form monolayers directly at the interface and soluble (hydrophilic, wet) surfactants (e.g., lipopolysaccharides) that dominate the surfactant pool in the bulk water phase accumulate. In contrast to dense monolayers formed by the insoluble surfactants that act as a potential static barrier for mass exchange, soluble surfactants establish concentration-dependent interfacial adsorption equilibria, which do not show static barrier effects (Springer and Pigford, 1970). For natural environments, where a complex mixture of surfactants is present, the overall effect on gas-exchange resulting from a subtle interplay of insoluble and soluble surfactants at the interface is difficult to predict. 
Experimental studies have revealed substantial suppression of the $k_{\mathrm{w}}$ values of various gases by surfactants in the laboratory (see e.g., Mesarchaki et al., 2015) and in the field (see e.g., Salter et al., 2011). During the UK SOLAS Deep Ocean Gas Exchange Experiment in the NE Atlantic Ocean, addition of (i) $\mathrm{SF}_{6} /{ }^{3} \mathrm{He}$ and (ii) $\mathrm{SF}_{6} /{ }^{3}$ He plus artificial surfactant showed that addition of the surfactant caused up to 55\% suppression of $k_{w}$ at wind speeds up to $11 \mathrm{~m} \mathrm{~s}^{-1}$ (Salter et al., 2011). Due to the practical difficulties of estimating $k_{w}$ for "naturally surfactant-enriched" vs. "surfactant-free" waters both in situ and in the laboratory, such experiments are conditioned by the addition of soluble or insoluble synthetic surfactants.

As of now the role of natural surfactants in modifying gas transfer velocities in the ocean is largely uncertain. Natural slicks of insoluble surfactants that may form under calm conditions tend to dissipate rapidly at high turbulence (Frew et al., 1990; Bock et al., 1999). The issue is further compounded by a high degree of spatial and temporal variability in total surfactant amount and in the chemical composition of the surfactant pool, both in the short-term and seasonally (Gašparović et al., 2011; Schmidt and Schneider, 2011; Wurl et al., 2011; Laß et al., 2013; Schneider-Zapp et al., 2014; Pereira et al., 2016). Compounds that contribute little to organic matter by mass, such as lipids, may have a strong influence on the physicochemical, and structural properties of the SML (Frka et al., 2012). Compositional variations in SML biosurfactants deriving from organic matter dynamics in natural waters and their specific impact on $k_{w}$ still needs to be assessed (Pogorzelski et al., 2006). For example, in Baltic Sea coastal waters a factor $\sim 2$ variability in seasonal $\mathrm{CO}_{2}$ uptake was related to productivity- (i.e., surfactant-) related variability in $k_{w}$ of only $20 \%$ (Schmidt and Schneider, 2011). Modeling studies suggested that surfactants in the SML can reduce net oceanic $\mathrm{CO}_{2}$ uptake by 15-50\% (Asher, 1997; Tsai and Liu, 2003; Wurl et al., 2016). A recent study of $\mathrm{N}_{2} \mathrm{O}$ air-sea and diapycnal fluxes in the eastern tropical North Atlantic (including the upwelling off Mauritania, NW Africa) revealed that the mean air-sea flux, calculated with a common gas exchange approach, is about four times larger than the mean diapycnal flux into the mixed layer (Kock et al., 2012). Neither vertical advection nor biological production could explain this discrepancy. Instead, flux calculations using an air-sea exchange parameterization that took account of the effect of surfactants in the SML were in good agreement with the $\mathrm{N}_{2} \mathrm{O}$ diapycnal fluxes. This indicates that surfactants, especially in areas of high biological productivity, may exert a large dampening effect on the air-sea exchange of $\mathrm{N}_{2} \mathrm{O}$ (Kock et al., 2012).

Very strong accumulation of organic matter in the SML can lead to the formation of surface slicks, which can be distinguished from non-slick surfaces by their different reflectance properties that result from increased wave damping (Figure 2). Slicks are frequently observed in the oceans, but it remains unclear whether they are specific cases of surfactant enrichment or whether they should be regarded as an exaggerated SML including chemical and biological constituents. It has recently been proposed that the accumulation of organic gels in the SML may directly suppress gas exchange by virtue of their inherently high surface to volume ratio, acting as a diffusional barrier (Engel and Galgani, 2016;

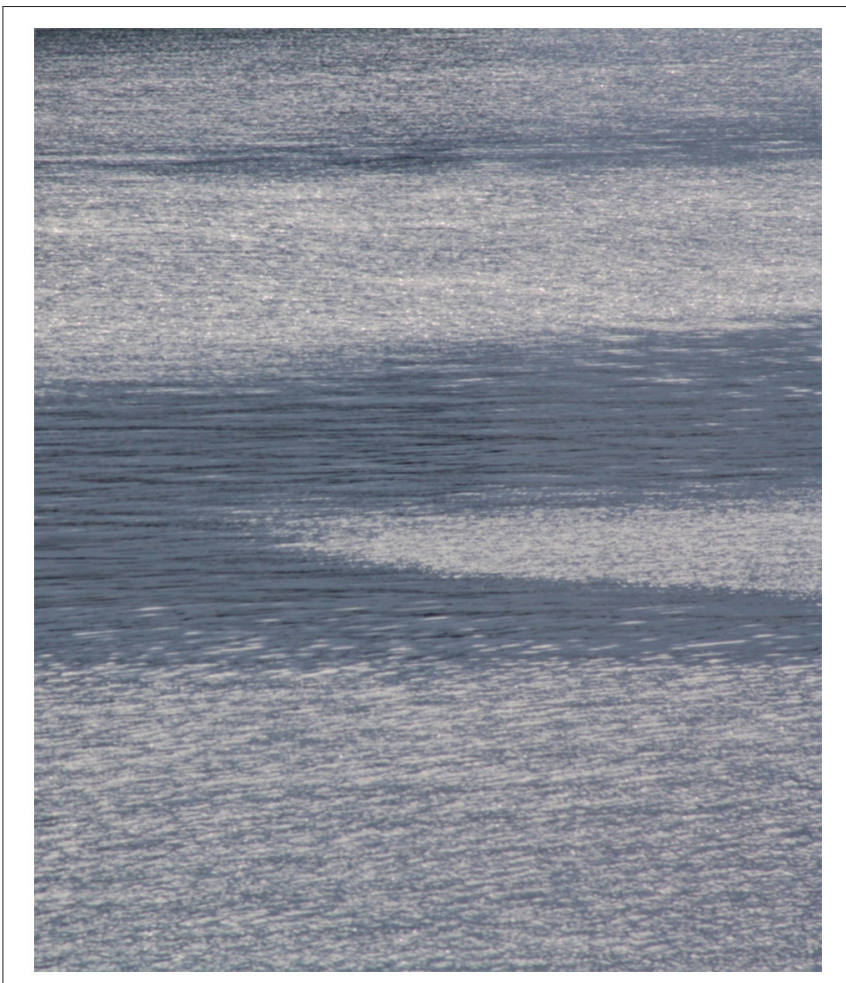

FIGURE 2 | Surface slicks attenuate small and capillary waves in the upper $\mathrm{cm}$ of the ocean, which causes a significant reduction of the glittering effect of sun beams. Photo by: Angela Stippkugel.

Wurl et al., 2016). So far, it has not been demonstrated how the coverage by a "gelatinous surface layer" could significantly affect the exchange of gas, heat, and momentum between the ocean and atmosphere. Moreover, spatial and temporal accumulation of gel particles in the SML may be highly variable, probably affecting instantaneous transfer velocities rather than time-integrated gas exchange fluxes. Clearly, further research is needed to understand the formation, composition and stability of surfactants/surface slicks as well as to evaluate their importance for gas fluxes across the air-sea interface.

Heterogeneous oxidation processes occurring directly at the air-sea interface are another example of a potential specific surface film effect. For example, the reaction between gaseous ozone and aqueous iodide or bromide is hypothesized to contribute to the formation of volatile halogenated species (Carpenter and Nightingale, 2015), which, when transferred to the atmosphere, can affect its oxidation capacity and potentially be important for secondary particle formation. Similarly, the products of photosensitized reactions depend on the molecular environment; a high concentration of surfactants may increase the probability of molecular contact between reactive species involved in the photochemistry. Such conditions could influence the reaction rate and result in additional products other than those originating from the corresponding bulk reaction. Recently $\mathrm{Fu}$ et al. (2015) demonstrated that the irradiation of an organic monolayer in the presence of 
photosensitizers at the water surface leads to the release of unexpected unsaturated volatile organic compounds to the gas phase. Previously, unsaturated compounds were thought to be generated from biological activity alone. Further, Ciuraru et al. (2015a,b) showed that photosensitized reactions involving the SML produce a series of unsaturated volatile organic compounds and significant amounts of isoprene. It is well-known that in seawater unsaturated compounds including isoprene are produced by various biological processes. However, these recent studies suggest that interfacial photosensitized chemistry is an important source of unsaturated compounds even in the absence of any biological sources in the marine boundary layer (Tinel et al., 2016), clearly implying a global impact of reactions at the air-sea interface. There is huge potential for hitherto undiscovered chemical conversions that might take place under the special conditions of the SML. These could include the aforementioned photosensitization processes, but there is also potential for complex photochemistry, the generation of novel radicals and their involvement in a range of reactions in the special environment of the oceanic SML. Further experimental work, both in the laboratory and in the field, as well as the development of numerical models is necessary to untangle the complex kinetics of SML mediated chemistry and photochemistry and to better constrain their roles in oceanatmosphere coupling.

\section{DO WE NEED TO CONSIDER THE AIR-SEA INTERFACE WHEN ESTIMATING THE MARINE SOURCE OF ORGANIC ATMOSPHERIC AEROSOLS?}

Marine aerosol particles are predominantly produced directly at the sea surface due to the interaction between wind and waves ("bubble bursting") or indirectly by gas-to-particle conversion following the release of oceanic trace gases to the atmosphere. Air-sea-gas exchange produces secondary organic aerosol (SOA) precursors during calm and windy conditions. In contrast, the formation of sea spray aerosol (SSA) is triggered mainly in white caps under windy conditions and therefore is conceptually rather different. An as yet relatively unknown aspect is the role of bubbles ascending in the water-column as a transport vector for organic matter into and out of the SML via aerosol formation. In the water column the upward transport of organic matter is most likely associated with its adsorption onto floating bubbles that eventually approach the SML (Hunter, 1980). The formation and buoyancy of bubbles depends on wave characteristics and turbulence (e.g., Garrett et al., 2000; Deane and Stokes, 2002) and they are known to modulate air-sea gas exchange (e.g., Keeling, 1993; Liang et al., 2013). Bubble dynamics is also of primary concern when quantifying the formation of jet and film drops at the SML that facilitate the emission of primary aerosols into the atmosphere (e.g., Blanchard, 1964; Resch, 1986; Woolf et al., 1987). There is evidence to suggest that surfactants may modify the characteristics of the bubble plume and may increase the stability of bubble films, thus leading to enhanced thinning of the bubbles prior to bursting (Modini et al., 2013).
Organic matter transferred from the SML into the atmosphere by wave breaking and bubble bursting has been linked to the formation of cloud condensation nuclei (CCN) (Russell et al., 2010; Quinn and Bates, 2011). Consequently, the quantification of primary organic aerosol formation and emission is of particular relevance for climate modeling (Navakov and Penner, 1993; O’Dowd et al., 2004; McCoy et al., 2015; Wilson et al., 2015). So far, a detailed understanding of how the physical characteristics and chemical composition of marine aerosol particles may affect solar radiation transfer and cloud processes is lacking (de Leeuw et al., 2011; Gantt and Meskhidze, 2013). The numerous measurements of the atmospheric aerosol burden over pristine marine regions available today indicate that organic matter, including bacteria and viruses (Aller et al., 2005), is one constituent that is highly enriched in marine aerosols with respect to seawater (Quinn et al., 2015 and references therein). Thereby, the smaller the particles the higher the organic matter enrichment (O’Dowd et al., 2004).

Although much effort has been directed toward analyzing the organic matter from aerosols in general, the role of the SML in determining the mixing state of sea-salt and organics, the chemical fractionation of the organic matter, and the relative atmospheric enrichment remain unclear (Facchini et al., 2008; Collins et al., 2013; Gantt and Meskhidze, 2013; Quinn et al., 2015; Ceburnis et al., 2016).

Recently much attention has been paid to the gel-like compounds that are found to be accumulated in the SML and which have also been detected in cloud water and in aerosol particles over the Arctic Ocean (Orellana et al., 2011; Galgani et al., 2016). It was concluded that this gel-like organic matter originating in the SML of open leads between the ice masses of the central Arctic Ocean can account for a substantial fraction of the Arctic summer aerosol (Leck and Bigg, 2005a,b). Such gellike phytoplankton exudates in SML-derived submicron aerosol particles are hypothesized to eventually become Ice Nucleating Particles (INPs) in the atmosphere and to affect the lifetime, precipitation, and radiation potential of clouds (Wilson et al., 2015). This marine biogenic source of atmospheric ice-nucleating particles is probably most relevant in remote regions, such as at the poles or in the Southern Ocean. A direct coupling between polar ocean biology and cloud formation could have important feed-back implications given that biological processes are sensitive to climate change.

The precise and selective mechanisms by which organic components transfer from the ocean to the atmosphere via the SML are however still poorly understood. Surface activity of the organic constituents is thought to play a key role in the transfer process, by driving strong partitioning of surface-active molecular components to the SML and to the surface of bubble films. The latter of these is an important source of film drop aerosol (Burrows et al., 2014). SchmittKopplin et al. (2012) pointed out that not all compounds are transported to the same extent; rather there is a chemo-selective transfer of natural organic compounds (typically surfactants) from seawater to the atmosphere via bubble bursting. Cochran et al. (2016) recently demonstrated in a laboratory-based study that theoretically-predicted relative coverages of the air-water 
interface by surface-active organic molecules predicted their relative contributions to artificially-generated sea spray aerosol. It remains unclear whether organic matter already enriched within the SML or adsorbed to rising bubbles contributes most to primary organic aerosol emissions.

Moreover, it is still unknown whether the organic composition of aerosols reflects short term biological dynamics, such as phytoplankton blooms and viral demise (O'Dowd et al., 2004, 2015), or rather the composition of the bulk dissolved organic matter pool that is rather invariant in time and space (Quinn et al., 2014).

Of particular relevance for climate, due to the potential impacts on cloud formation and properties, is the quantification of primary organic aerosol formation and emission (Navakov and Penner, 1993; O’Dowd et al., 2004; McCoy et al., 2015; Wilson et al., 2015). Methods of SSA parameterization are often based on wind speed normalized to a height of $10 \mathrm{~m}$ $\left(\mathrm{u}_{10}\right)$. However, it has been suggested that more fundamental quantities related to seawater, such as wind stress at the sea surface, seawater temperature, and whitecap fraction might help to improve the parameterization of SSA fluxes (Lewis and Schwartz, 2004; de Leeuw et al., 2011). In this direction, Ovadnevaite et al. (2014) developed a source function including the Reynolds number instead of the wind speed. This approach combines the effects of wind history and wave state along with sea surface temperature and salinity in one parameter. Salter et al. (2015) derived a temperature-dependent sea spray source function and employed it in large-scale models. Recent work indicates that the SML covers the ocean to a significant extent and is relevant over a range of oceanic conditions (Sabbaghzadeh et al., 2017). Following wave breaking, the SML reforms within seconds (Wurl et al., 2011). Furthermore, breaking waves promote the formation of the SML through ascending air bubble plumes and bring molecules and particles back to the surface. However, adequate knowledge of the production mechanisms of SSA and the role of processes in seawater especially in the SML, is lacking. In an artificial bubbling experiment, Frossard et al. (2014) observed that the presence of a thick stable SML might change SSA composition. They speculated that high surfactant concentrations enhance the persistence of bubbles at the sea surface and cause the drainage of more soluble compounds to leave the less soluble compounds enriched on the bubbles. The result is a larger fraction of non-soluble compounds on SSA. While this hypothesis warrants further examination, the inclusion of the SML in SSA parameterizations could be important for devising realistic model parameterizations.

Gantt et al. (2011) proposed a conceptual relationship between the organic mass fraction of SSA and wind speed, which imposes the presence of an air-sea enriched interface such as the SML. Their parameterization highlights the influence of the SML on the oceanic export of organic matter in the direction of a high organic enrichment in SSA at low wind speeds, when the sea surface is strongly enriched in organic material. Under stronger winds, sea spray production is increased but the organic content of SSA is reduced because the enhanced mixing of the SML with bulk water results in a lower enrichment of organic material in the SML. However, the suitability of chlorophyll- $a$ as proxy for biological activity-currently used in modeling the organic aerosol matter-is under debate, as it may not ideally reflect the surface ocean's organic carbon pool, and may therefore not represent the portion relevant for microlayer exchange processes (Sabbaghzadeh et al., 2017). Other studies have found high enrichments in organic aerosol to be connected with concentrations of dimethyl sulfide (DMS) (Bates et al., 2012) or heterotrophic bacteria (Prather et al., 2013). DMS is an indicator of oxidative stress and phytoplankton cell lysis (Wolfe and Steinke, 1996). The correlation between DMS and SSA organics suggests that the organics derive from cell exudate related to phytoplankton cell lysis (Bates et al., 2012). First attempts to introduce a novel framework for parameterizing the organic fraction in sea-spray aerosol were based on a competitive Langmuir adsorption equilibrium at bubble surfaces rather than chlorophyll-a abundance (Burrows et al., 2014, 2016). This new modeling approach links a global marine biogeochemistry model with aerosol chemical composition, incorporating the SML as an enriching interface. There remain even more basic questions about how the physical characteristics and chemical composition of marine aerosol particles may affect solar radiation transfer and cloud processes (de Leeuw et al., 2011; Gantt and Meskhidze, 2013; McCoy et al., 2015).

An improved comprehension of biogeochemical processes at the ocean surface, in particular those involving the SML as an important and determining interface, will make a crucial contribution to the reduction of uncertainties inherent in predicting aerosol-climate feedbacks. Ultimately, a greater understanding of SML processes and the relevance of marine aerosols for the climate system will greatly improve our understanding of the wider Earth system.

\section{WHAT IS NEEDED TO STUDY THE AIR-SEA INTERFACE?}

The several open questions addressed in this review demonstrate the strong interdependence of diverse biological (e.g., production, alteration, and decomposition of organic matter), chemical (e.g., photochemistry), and physical (e.g., coagulation, transport efficiencies) processes in the SML. A better understanding of the interactions and feedbacks between these processes is a necessary first step toward a more comprehensive understanding of the ocean/atmosphere interface. This also must implicate a better understanding of the temporal (from diurnal to seasonal) and spatial (from local heterogeneity to different oceanic regions) variability affecting the rates and composition of primary aerosols as well as the air-sea exchange of gases. To establish consistent links between biological diversity, the production and fate of organic matter, wave dynamics, bubble intrusion, the generation and dissipation of turbulence, gas exchange, and the emission of primary aerosols demands a truly interdisciplinary research approach. This in turn imposes new challenges in terms of comprehending the interdependencies between physical, chemical, and biological processes on the nano- and microscale. 
Representatively sampling the air-sea interface is still one of the largest practical challenges to SML-related studies (Figure 3). For example, it is currently not possible to routinely resolve layering within the SML under ambient conditions and to separate the thin film effects of a surface nanolayer (i.e., the uppermost molecular layer directly at the air-water interface) from overall SML effects (Figure 1). The nano- and underlying sublayers concentrate organic and inorganic compounds as well as microorganisms beyond their average concentrations commonly found in surface ocean waters, but during sampling the "true" SML concentrations inevitably become diluted by mixing with underlying seawater.

Whereas measurements of the surface tension and surfacepressure isotherms can be taken as a physical measure of static and dynamic thin film characteristics (Bock and Frew, 1993), the underlying chemical composition derived from the analysis of samples collected by standard SML sampling techniques (screen, glass plate, etc., see Cunliffe and Wurl, 2014) is not representative of the uppermost layers. Recently, in an effort to close this critical knowledge gap, non-linear vibrational sum-frequency generation spectroscopy (SFG) was introduced as a surface-selective analytical technique. SFG provides new molecular insights into the structure, chemical composition, and seasonality of surface films (Laß et al., 2010), which will likely help to resolve possible mechanisms of organic enrichment at the surface (Burrows et al., 2016). Consistent with the current view of a carbohydrate rich SML and the importance of bacterial degradation for surfactant enrichment (Cunliffe et al., 2013; Kurata et al., 2016), first SFG measurements revealed dense natural surfactant nanolayers with lipid-like compounds predominantly stemming from the soluble surfactant pool (Laß and Friedrichs, 2011) and a seasonal trend that was not directly related to phytoplankton abundance (Laß et al., 2013). Yet another SFG study supported the need for additional chemical interaction terms in process models developed for understanding the organic content of SSA. These extra terms are needed to account for the interaction between soluble monosaccharides and insoluble lipid surfactant monolayers (Burrows et al., 2016).

Current sampling methods, e.g., with screens or glass plates (Cunliffe and Wurl, 2014) do not permit any meaningful sampling of gases from the SML. A variety of climate relevant gases such as $\mathrm{CO}, \mathrm{CO}_{2}, \mathrm{NO}$, and halocarbons are produced or consumed in the SML (Bakker et al., 2014; Liss et al., 2014; Carpenter and Nightingale, 2015). Determining gas fluxes under in situ conditions therefore requires new sampling approaches.

Furthermore, physical, chemical and biological processes in the SML show strong mutual dependency, extensive dynamics and a strong selectivity with respect to other bulk ocean characteristics. The intimate contact of organic and inorganic compounds facilitates unusual chemical reactions, in particular
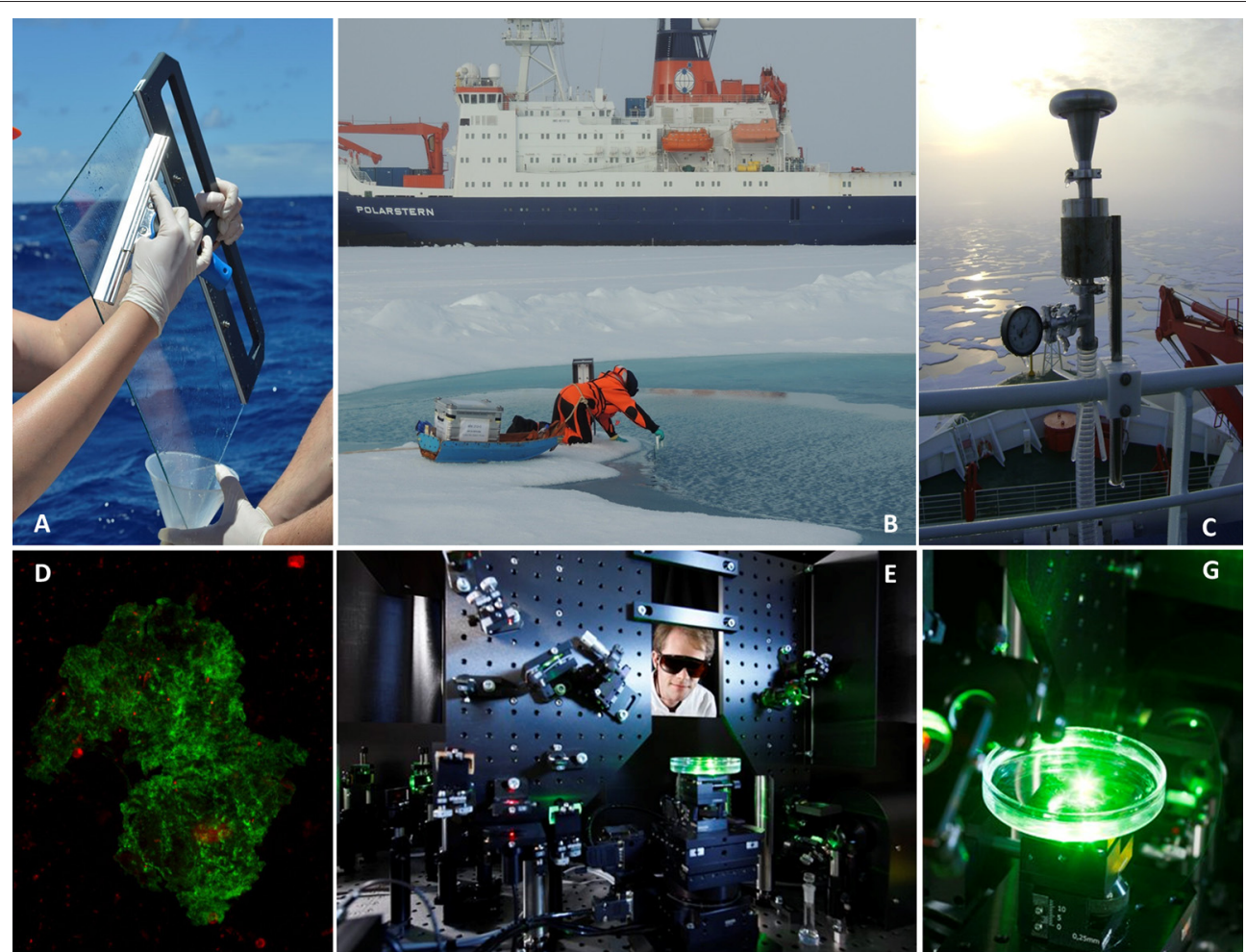

FIGURE 3 | Material accumulating in the SML can be sampled with a glass plate from the ocean (A) and melt ponds (B), or by using an aerosol collector (C). Advanced analysis of organic components in the SML, such as gel particles colonized by bacteria (D), reveal structural properties of the gelatinous SML matrix and nanolayer, which has been studied by new methods such as sum frequency generation spectroscopy (SFG) (E,G). Photos by: M. van Pinxteren, A. Stecher, L. Galgani, B. Zäncker, R. Frommann/Future Ocean. Written, informed consent has been obtained for the publication of images showing individuals. 
under conditions of sunlight exposure (Blough, 1997). Here, metal-catalyzed redox reactions and photochemistry prevail. Again, this implies the need for improved sampling strategies as well as thorough characterization, for both in vitro and in situ observation.

Another major challenge is the intrinsic chemical and biological complexity of the SML. To date, a large fraction of the organic matter in the SML and in derived aerosol particles remains unidentified at the molecular level. The presence of e.g., organic amino compounds and carbonyl compounds in marine aerosol particles and in the SML clearly demonstrates the link between the ocean and the atmosphere, but individual compound analysis can only explain a minor part of the total organic matter pool (van Pinxteren et al., 2012; van Pinxteren and Herrmann, 2013). Revealing the molecular complexity of marine organic matter, as well as explaining how organisms, chemical reactions and physical processes affect organic matter composition and size distribution, may be the key to better describe processes in the SML, and to improve computations of the sources and sinks of organic aerosols in ocean-atmosphere models.

Extrapolating the variability in SML properties across ocean basins from coastal waters to oligotrophic gyres is another substantial challenge and may still be some way off. While satellite-based estimates of global gas transfer velocities in water $\left(k_{w}\right)$ using the distributions of surfactant proxies such as chlorophyll- $a$ have been developed (e.g., Liu et al., 2000; Lin et al., 2002; Tsai and Liu, 2003), a universal relationship linking chlorophyll- $a$, total surfactant, and $k_{w}$ remains both unproven and unlikely (Upstill-Goddard, 2006; Sabbaghzadeh et al., 2017). New observational approaches and new experimental techniques to study gas-exchange in natural, un-amended seawater (e.g., Schneider-Zapp et al., 2014; Pereira et al., 2016) will be required to further resolve this issue. Such approaches will need to address contrasting biogeochemical, seasonal and turbulence regimes.

Models can be applied as tools for assessing those uncertainties that relate to effects of the SML on air-sea exchange processes. The exchange of gases between phases depends on both the solubility-corrected concentration difference between the ocean and atmosphere and on $k_{w}$, which controls the kinetics of gas exchange (Liss and Slater, 1974; Johnson, 2010). A microlayer, whether it be a surface monolayer or a slick, can affect both of these properties: (i) through modifying dissolved gas concentrations (e.g., by enrichment of SML related production); (ii) by modifying solubility via differences in temperature, salinity or the organic matrix between surface and bulk waters; and (iii) by modifying $k_{w}$ as described above (Johnson et al., 2011). Furthermore, the chemical and/or biological alteration of concentration gradients through the mass boundary layer at a rate sufficient to modify the apparent value of $k_{w}$ is likely to be enhanced by a biologically and chemically enriched, irradiated surface layer (e.g., Beale et al., 2014; Yang et al., 2014).

To date only a few modeling studies have explicitly resolved the interfacial transfer of mass (including gas) through the SML. Cen-Lin and Tzung-May (2013) proposed a dynamic three-layer model of gas transfer that considers a SML in which microbial activity and photochemical reactions can modify concentrations. Their model was applied to determine the exchange of acetone in the Pacific, which demonstrated that the characteristics of the SML can explain significant discrepancies between observed fluxes and those predicted by a simple gas exchange model without any SML effect. Similarly, Yang et al. (2014) applied a simple chemical enhancement model to account for discrepancies between the predicted and observed fluxes of acetaldehyde in the Atlantic (although they did not explicitly consider the effect of a discontinuous microlayer). Such models currently have severe limitations in predictive skill, mainly due to uncertainties with respect to the underlying complexity of parameterisations and the associated quantification of credible parameter values. Nevertheless, by providing insight into the micro- and nano-scale processes that are unresolved by current measurement approaches, they are likely to prove an essential tool in the interpretation and integration of field, mesocosm, and laboratory measurements of air-sea gas exchange in the presence of surface films.

\section{NEW RESEARCH PRIORITIES AND STRATEGIES FOR THEIR IMPLEMENTATION}

It is clear from this review that the fundamental role of the SML in the interactions of the surface ocean with the lower atmosphere requires a critical reassessment. The exchange of momentum, energy (heat), and mass (gases and particles) across the ocean/atmosphere interface interacts with the physical structure, chemical composition and reactivity, and the biology of both the surface ocean and the lower atmosphere. Processes within the SML and exchange across its upper and lower boundaries impact the Earth's climate. Conversely, global environmental change, (warming, acidification, eutrophication, pollution) modifies SML processes and thereby alters the conditions of the upper ocean and lower atmosphere, with largely unknown consequences for the Earth system. It is important to note that these surface ocean/lower atmosphere feedback processes operate across a wide range of spatial and temporal scales, from molecular to global and from millisecond to decadal. Thus, an overarching goal of future SML research should be to develop a standard model of the SML that includes all relevant physical, chemical, and biological processes necessary to understand the role of the SML in the Earth system.

Priority research tasks in this context include:

(1) To identify and quantify the physical processes driving the dynamics of the SML and across the ocean/atmosphere interface;

(2) To characterize and quantify the chemical and biological composition of the SML, including organic compounds, microorganisms, gases, metals, and anthropogenic pollutants;

(3) To identify and quantify the biological (e.g., microbial) and chemical processes that transform the chemical and biological composition of the SML;

(4) To understand the role of organisms in the SML in influencing SML characteristics as well as exchange processes; 
(5) To significantly improve model approaches for computing gas exchange across the ocean/atmosphere interface;

(6) To investigate the role of physical processes and SML composition for atmospheric aerosol formation;

(7) To develop remote sensors and remote sensing algorithms to facilitate the measurement of (natural and anthropogenic) global-scale surfactant distributions and exchange processes with high temporal resolution;

(8) To identify, quantify, and predict SML/global change feedbacks.

Investigation of the SML remains especially challenging because of its limited accessibility and the patchiness of the processes that take place within it. Its future study will require representative and standardized sampling (see e.g., Cunliffe and Wurl, 2014), the development of new analytical methods (e.g., in-situ SML measurements), and new observational and experimental frameworks (e.g., SML tracer studies). The objective of these should be to facilitate fully representative parameterizations of SML processes in numerical models. Moreover, micrometeorological/oceanographic modelers should strive toward developing a model of the SML that is able to predict the water depth at which key SML properties change. This will allow us to begin to move away from the current (and mostly inadequate) techniques for SML sampling.

To this end it is evident that only multidisciplinary research initiatives, at both national and international levels, can effectively address the several open questions identified in this review. Joint projects should link laboratory, field, model and remote sensing approaches to better understand the complex interplay of the various physical, biological, and chemical processes operating in the SML and across the ocean/atmosphere interface. Furthermore, we should make use of expertise across transdisciplinary sectors, such as commercial detergents industries and chemical companies.

Following the proposal of Cunliffe et al. (2013), we advocate the establishment of a network of time-series measurements designed to help us better understand both regional variability and long-term trends in the physical structure, chemical composition, and biogeochemical processes of the SML. This could be achieved by augmenting ongoing time-series programmes in the open ocean (e.g., HOT, BATS, CVOO/CVAO, Line P, LTER HAUSGARTEN, and others) and in coastal shelf seas (e.g., Boknis Eck, Helgoland Roads, Saanich Inlet, Western Channel Observatory, Time Series site off Conception, CaTS, and others) with the appropriate instrumentation for SML study. Such an approach is critical for understanding the effects on the SML of seasonal events such as phytoplankton blooms, dry/wet deposition and storms in a range of ocean regions. In addition, time-series measurements in remote ocean regions

\section{REFERENCES}

Agogue, H., Casamayor, E. O., Bourrain, M., Obernosterer, I., Joux, F., Herndl, G. J., et al. (2005). A survey on bacteria inhabiting the sea surface microlayer of coastal ecosystems. FEMS Microbiol. Ecol. 54, 269-280. doi: 10.1016/j.femsec.2005.04.002 where minimal anthropogenic influence might reasonably be expected, such as in the Arctic and Southern Oceans, should be established as reference measurements.

Complementary to (ship-borne) field measurements, remote sensing and modeling efforts, joint wind/wave tank studies simulating the role of the SML in air/sea gas exchange and aerosol formation under controlled (including extreme, e.g., high wind speed) conditions should be conducted. The use of unmanned drones operated from research vessels or land stations also represents an exciting opportunity for future SML research.

National and international collaboration will be an integral aspect of the envisioned multidisciplinary SML studies. An improved understanding of the SML will contribute to our appreciation of the crucial role of the ocean/atmosphere interface in societal-relevant issues such as climate change, ocean acidification, air quality (pollution), and the overall health of the ocean. SML research should be a continuing longterm focus of international research initiatives such as SOLAS (Surface Ocean-Lower Atmosphere Study: www.solas-int.org) and Future Earth (www.futureearth.org).

\section{AUTHOR CONTRIBUTIONS}

All authors listed, have made substantial, direct and intellectual contribution to the work, and approved it for publication.

\section{ACKNOWLEDGMENTS}

This manuscript is an outcome of "The Ocean Surface Microlayer and Biogeochemical Feedbacks in the Earth System," an international workshop held from 1-3 July 2015 at the Wissenschaftszentrum, Kiel. We thank the Cluster of Excellence "The Future Ocean" for its financial support of the workshop in the framework of the semester topic "Ocean Interfaces From Nanoscales to Global Impact." We would particularly like to acknowledge the excellent organization of the workshop by Anke Schneider and we thank all of those workshop participants who contributed their further insights into SML research, especially Enno Bahlmann, Stefan Barthel, Tim Bates, Alexandra Dabrowski, Cayla Dean, Tim Fischer, Tobias Hahn, Inga Hense, Helmke Hepach, Bernd Jähne, Annette Kock, Kerstin Krall, Kristian Lass, Caroline Leck, Christa Marandino, Birgit Quack, Rüdiger Röttgers, Ina Tegen, Domenico Velotto, Douglas Wallace, and Oliver Wurl. This is a contribution to the international Surface Ocean Lower Atmosphere Study (SOLAS). This is also a contribution to the international Scientific Committee of Ocean Research (SCOR) SML working group (WG 141) and PMEL contribution number 4626. SB was supported by the U.S. Department of Energy Office of Science. microlayer as a source of viral and bacterial enrichment in marine aerosols. J. Aerosol Sci. 36, 801-812. doi: 10.1016/j.jaerosci.2004.10.012

Asher, W. (1997). "The sea surface and global change," in The Sea-Surface Microlayer and its Effect on Global Air-Sea Gas Transfer, eds P.S. Liss and R. Duce (Cambridge University Press), 251-286. 
Astrahan, P., Herut, B., Paytan, A., and Rahav, E. (2016). The impact of dry atmospheric deposition on the sea-surface microlayer in the SE Mediterranean Sea: an experimental approach. Front. Mar. Sci. 3:222. doi: 10.3389/fmars.2016.00222

Bakker, D. C. E., Bange, H. W., Gruber, N., Johannessen, T., Upstill-Goddard, R. C., Borges, A. V., et al. (2014). "Air-sea interactions of natural longlived greenhouse gases $(\mathrm{CO} 2, \mathrm{~N} 2 \mathrm{O}, \mathrm{CH} 4)$ in a changing climate," in OceanAtmosphere Interactions of Gases and Particles, eds P.S. Liss and M.T. Johnson (Heidelberg: Springer), 113-169.

Bailey, C. A., Neihof, R. A., and Tabor, P. S. (1983). Inhibitory effect of solar radiation on amino acid uptake in chesapeake bay bacteria. Appl. Environ. Microbiol. 46, 44-49.

Banerjee, S., Lakehal, D., and Fulgosi, M. (2004). Surface divergence models for scalar exchange between turbulent streams. Int. J. Multiphase Flow 30, 963-977. doi: 10.1016/j.ijmultiphaseflow.2004.05.004

Bates, T. S., Quinn, P. K., Frossard, A. A., Russell, L. M., Hakala, J., Petäjä, T., et al. (2012). Measurements of ocean derived aerosol off the coast of California. J. Geophys. Res. 117, 1-13. doi: 10.1029/2012JD017588

Beale, R., Johnson, M. T., Liss, P. S., and Nightingale, P. D. (2014). "Air-sea exchange of marine trace gases", in Treatise on Geochemistry, 2nd Edn, Vol. 8: The Oceans and Marine Geochemistry, eds. M. J. Mottl, and H. Elderfield, (Oxford: Elsevier), 53-92.

Blanchard, D. C. (1964). Sea-to-air transport of surface active material. Science 146, 319-397. doi: 10.1126/science.146.3642.396

Blank, M. (1962). Monolayer permeability and the properties of natural membranes. J. Phys. Chem. 66, 1911-1918. doi: 10.1021/j100816a026

Blough, N. V. (1997). "Photochemistry in the sea-surface microlayer," in The Sea Surface and Global Change, eds P.S. Liss and R. A. Duce (New York, NY: Cambridge University Press), 383-424.

Bock, E. J., and Frew, N. M. (1993). Static and dynamic response of natural multicomponent oceanic surface films to compression and dilation: laboratory and field observations. J. Geophys. Res. 98, 14599-14617. doi: $10.1029 / 93 J C 00428$

Bock, E. J., Hara, T., Frew, N. M., and McGillis, W. R. (1999). Relationship between air-sea gas transfer and short wind waves. J. Geophys. Res. 104, 25821-25831. doi: 10.1029/1999JC900200

Burrows, S. M., Gobrogge, E., Fu, L., Link, K., Elliott, S. M., Wang, H., et al. (2016). OCEANFILMS-2: representing coadsorption of saccharides in marine films and potential impacts on modeled marine aerosol chemistry. Geophys. Res. Lett. 43, 8306-8313. doi: 10.1002/2016GL069070

Burrows, S. M., Ogunro, O., Frossard, A. A., Russell, L. M., Rasch, P. J., and Elliott, S. M. (2014). A physically based framework for modeling the organic fractionation of sea spray aerosol from bubble film Langmuir equilibria. Atmos. Chem. Phys. 14, 13-601. doi: 10.5194/acp-14-13601-2014

Calleja, M. L., Duarte, C. M., Navarro, N., and Agustí, S. (2005). Control of air-sea $\mathrm{CO}_{2}$ disequilibria in the subtropical NE Atlantic by planktonic metabolism under the ocean skin. Geophys. Res. Lett. 32:L08606. doi: 10.1029/2004GL022120

Carlucci, A. F., Craven, D. B., and Henrichs, S. M. (1985). Surface-film microheterotrophs: amino acid metabolism and solar radiation effects on their activities. Mar. Biol. 85:13. doi: 10.1007/BF00396410

Carlucci, A. F., Wolgast, D. M., and Craven, D. B. (1992). Microbial populations in surface films: amino acid dynamics in nearshore and offshore waters off Southern California. J. GeoPhys. Res. 97, 5271-5280. doi: 10.1029/ 91JC02614

Carpenter, L. J., and Nightingale, P. D. (2015). Chemistry and release of gases from the surface ocean. Chem. Rev. 115, 4015-4034. doi: 10.1021/cr5007123

Ceburnis, D., Masalaite, A., Ovadnevaite, J., Garbaras, A., Remeikis, V., Maenhaut, W., et al. (2016). Stable isotopes measurements reveal dual carbon pools contributing to organic matter enrichment in marine aerosol. Sci. Rep. 6:36675. doi: $10.1038 /$ srep 36675

Cen-Lin, H., and Tzung-May, F. (2013). Air-sea exchange of volatile organic compounds: a new model with microlayer effects. Atmos. Ocean. Sci. Lett. 6, 97-102. doi: 10.1002/2017GL072975

Ciuraru, R., Fine, L., van Pinxteren, M., D’Anna, B., Herrmann, H., and George, C. (2015a). Photosensitized production of functionalized and unsaturated organic compounds at the air-sea interface. Sci. Rep. 5:12741. doi: 10.1038/srep 12741
Ciuraru, R., Fine, L., van Pinxteren, M., D’Anna, B., Herrmann, H., and George, C. (2015b). Unravelling new processes at interfaces: photochemical isoprene production at the sea surface. Environ. Sci. Technol. 2015, 13199-13205. doi: 10.1021 /acs.est.5b02388

Cochran, R. E., Laskina, O., Jayarathne, T., Laskin, A., Laskin, J., Lin, P., et al. (2016). Analysis of organic anionic surfactants in fine and coarse fractions of freshly emitted sea spray aerosol. Environ. Sci. Technol. 50, 2477-2486. doi: 10.1021/acs.est.5b04053

Collins, D. B., Ault, A. P., Moffet, R C., Ruppel, M. J., Cuadra-Rodriguez, L A., Guasco, T. L., et al. (2013). Impact of marine biogeochemistry on the chemical mixing state and cloud forming ability of nascent sea spray aerosol. J. Geophys. Res. Atmos. 118, 8553-8565. doi: 10.1002/jgrd.50598

Conrad, R., and Seiler, W. (1988). Influence of the surface microlayer on the flux of nonconservative trace gases $(\mathrm{CO}, \mathrm{H} 2, \mathrm{CH} 4, \mathrm{~N} 2 \mathrm{O})$ across the ocean-atmosphere interface. J. Atmos. Chem. 6, 83-94. doi: 10.1007/BF00048333

Cunliffe, M., and Wurl, O. (2014). Guide to best practices to study the ocean's surface," in Occasional Publications of the Marine Biological Association of the United Kingdom, (Plymouth), 118. Available online at:http://www.mba.ac.uk/NMBL/

Cunliffe, M., Engel, A., Frka, S., Gašparovic, B., Guitart, C., Murrell, J. C., et al. (2013). Sea surface microlayers: a unified physicochemical and biological perspective of the air-ocean interface. Prog. Oceanogr. 109, 104-116. doi: 10.1016/j.pocean.2012.08.004

Cunliffe, M., Harrison, E., Salter, M., Schafer, H., Upstill-Goddard, R. C., and Murrell, J. C. (2009a). Comparison and validation of sampling strategies for the molecular microbial ecological analysis of surface microlayers. Aquat. Microb. Ecol. 57, 69-77. doi: 10.3354/ame01330

Cunliffe, M., Salter, M., Mann, P. J., Whiteley, A. S., Upstill-Goddard, R. C., and Murrell, J. C. (2009b). Dissolved organic carbon and bacterial populations in the gelatinous surface microlayer of a Norwegian fjord mesocosm. FEMS Microbiol. Lett. 299, 248-254. doi: 10.1111/j.1574-6968.2009.01751.x

Cunliffe, M., Schafer, H., Harrison, E., Cleave, S., Upstill-Goddard, R., and Murrell, J. C. (2008). Phylogenetic and functional gene analysis of the bacterial and archaeal communities associated with the surface microlayer of an estuary. ISME J. 2, 776-789. doi: 10.1038/ismej.2008.28

Cunliffe, M., Upstill-Goddard, R. C., and Murrell, J. C. (2011). Microbiology of aquatic surface microlayers. FEMS Microbiol. Rev. 35, 233-246. doi: 10.1111/j.1574-6976.2010.00246.x

Cunliffe, M., Whiteley, A. S., Schäfer, H., Newbold, L., Oliver, A., and Murrell, J. C. (2009c). Comparison of bacterioneuston and bacterioplankton dynamics during a phytoplankton bloom in a fjord mesocosm. Appl. Environ. Microbiol. 75, 7173-7181. doi: 10.1128/AEM.01374-09

Danckwerts, P. V. (1951). Significance of liquid-film coefficients in gas absorption. Ind. Eng. Chem. 43, 1460-1467. doi: 10.1021/ie50498a055

de Leeuw, G., Andreas, E. L., Anguelova, M. D., Fairall, C. W., Lewis, E. R. O'Dowd, C., et al. (2011). Production flux of sea spray aerosol. Rev. Geophys. 49, 1-39. doi: 10.1029/2010RG000349

Deane, G. B., and Stokes, M. D. (2002). Scale dependence of bubble creation mechanisms in breaking waves. Nature 418, 839-844. doi: 10.1038/nature00967

Dutz, J., Klein Breteler, W. C. M., and Kramer, G. (2005). Inhibition of copepod feeding by exudates and transparent exopolymer particles (TEP) derived from a Phaeocystis globosa dominated phytoplankton community. Harmful Algae 4, 929-940. doi: 10.1016/j.hal.2004.12.003

Engel, A., and Galgani, L. (2016). The organic sea-surface microlayer in the upwelling region off the coast of Peru and potential implications for air-sea exchange processes. Biogeosciences 13, 989-1007. doi: 10.5194/bg-13-989-2016

Facchini, M. C., Rinaldi, M., Decesari, S., Carbone, C., Finessi, E., Mircea, M., et al. (2008). Primary sub-micron marine aerosol dominated by insoluble organic colloids and aggregates. Geophys. Res. Lett. 35, L17814. doi: 10.1029/2008GL034210

Franklin, M. P., McDonald, I. R.,Bourne, D. G., Owens, N. J. P., UpstillGoddard, R. C., and Murrell, C. J. (2005). Bacterial diversity in the bacterioneuston (sea surface microlayer): the bacterioneuston through the looking glass. Environ. Microbiol. 7, 723-736. doi: 10.1111/j.1462-2920.2004. 00736.x

Frew, N. M., Goldman, J. C., Dennett, M. R., and Johnson, A. S. (1990). Impact of phytoplankton-generated surfactants on air-sea gas exchange. J. Geophys. Res. 95, 3337-3351. doi: 10.1029/JC095iC03p03337 
Frka, S., Pogorzelski, S., Kozarac, Z., and Ćosović, B. (2012). Physicochemical signatures of natural sea films from Middle Adriatic stations. J. Phys. Chem. A 116, 6552-6559. doi: 10.1021/jp212430a

Frossard, A. A., Russell, L. M., Burrows, S. M., Elliott, S. M., Bates, T. S., and Quinn, P. K. (2014). Sources and composition of submicron organic mass in marine aerosol particles. J. Geophys. Res. Atmos. 119, 12977-13003. doi: 10.1002/2014JD021913

Frost, T. (1999). Environmental Controls of Air-Water Gas Exchange. Newcastle upon Tyne: University of Newcastle upon Tyne.

Fu, H., Ciuraru, R., Dupart, Y., Passananti, M., Tinel, L., Rossignol, S., et al. (2015). Photosensitized production of atmospherically reactive organic compounds at the air/aqueous interface. J. Am. Chem. Soc. 137, 8348-8351. doi: $10.1021 /$ jacs.5b04051

Galgani, L., Piontek, J., and Engel, A. (2016). Biopolymers form a gelatinous microlayer at the air-sea interface when Arctic sea ice melts. Sci. Rep. 6:29465. doi: $10.1038 /$ srep 29465

Galgani, L., Stolle, C., Endres, S., Schulz, K. G., and Engel, A. (2014). Effects of ocean acidification on the biogenic composition of the sea-surface microlayer: results from a mesocosm study. J. Geophys. Res. Oceans 119, 7911-7924. doi: 10.1002/2014JC010188

Gantt, B., and Meskhidze, N. (2013). The physical and chemical characteristics of marine primary organic aerosol: a review. Atmos. Chem. Phys. 13, 3979-3996. doi: 10.5194/acp-13-3979-2013

Gantt, B., Meskhidze, N., Facchini, M. C., Rinaldi, M., Ceburnis, D., and O’Dowd, C. D. (2011). Wind speed dependent size-resolved parameterization for the organic mass fraction of sea spray aerosol. Atmos. Chem. Phys. 11, 8777-8790. doi: 10.5194/acp-11-8777-2011

Garbe, C. S., Rutgersson, A., Boutin, J., Delille, B., Fairall, C. W., Gruber, N., et al. (2014). "Transfer across the air-sea interface," in Ocean-Atmosphere Interactions of Gases and Particles, eds P. S. Liss and M. T. Johnson (Berlin: Springer), $55-112$.

Garrett, C., Li, M., and Farmer, D. (2000). The connection between bubble size spectra and energy dissipation rates in the upper ocean. J. Phys. Oceanogr. 30, 2163-2171. doi: 10.1175/1520-0485(2000)030<2163:TCBBSS $>2$. $0 . \mathrm{CO} ; 2$

Gašparović, B., Djakovac, T., Tepic', N., and Degobbis, D. (2011). Relationships between surface-active organic substances, chlorophyll a and nutrients in the northern Adriatic Sea. Cont. Shelf Res. 31, 1149-1160. doi: 10.1016/j.csr.2011.04.010

Hardy, J. T. (1982). The sea-surface microlayer - biology, chemistry and anthropogenic enrichment. Prog. Oceanogr. 11, 307-328. doi: 10.1016/0079-6611(82)90001-5

Hardy, J. T., and Valett, M. (1981). Natural and microcosm phytoneuston communities of Sequim Bay, Washington. Estuar. Coast. Shelf Sci. 12, 3-12. doi: $10.1016 / \mathrm{S} 0302-3524(81) 80113-2$

Henrichs, S. M., and Williams, P. M. (1985). Dissolved and particulate amino acids and carbohydrates in the sea surface microlayer. Mar. Chem. 17, 141-163. doi: 10.1016/0304-4203(85)90070-2

Ho, D. T., Wanninkhof, R., Schlosser, P., Ullman, D. S., Hebert, D., and Sullivan, K. F. (2011). Toward a universal relationship between wind speed and gas exchange: gas transfer velocities measured with ${ }^{3} \mathrm{He} / \mathrm{SF}_{6}$ during the Southern ocean gas exchange experiment. J. Geophys. Res. Oceans 116, 1-13. doi: 10.1029/2010JC006854

Hunter, K. A. (1980). Processes affecting particulate trace metals in the sea surface microlayer. Mar. Chem. 9, 49-70. doi: 10.1016/0304-4203(80)90006-7

Hunter, K. A., and Liss, P. (1977). The input of organic material to the oceans: air-sea interactions and the organic chemical composition of the sea surface. Mar. Chem. 5, 361-379. doi: 10.1016/0304-4203(77) 90029-9

Jähne, B., and Haußecker, H. (1998). Air-water gas exchange. Annu. Rev. Fluid Mech. 30, 443-468. doi: 10.1146/annurev.fluid.30.1.443

Johnson, M. T. (2010). A numerical scheme to calculate temperature and salinity dependent air-water transfer velocities for any gas. Ocean Sci. 6, 913-932. doi: 10.5194/os-6-913-2010

Johnson, M. T., Hughes, C., Bell, T. G., and Liss, P. S. (2011). "A Rumsfeldian analysis of uncertainty in air-sea gas exchange," in Gas Transfer at Water Surfaces 2010, eds S. Komori, W. McGillis, and R. Kurose (Kyoto: Kyoto University Press), 464-484.
Keeling, R. F. (1993). On the role of large bubbles in air-sea gas exchange and supersaturation in the ocean. J. Mar. Res. 51, 237-271. doi: $10.1357 / 0022240933223800$

Kock, A., Schafstall, J., Brandt, P., Dengler, M., and Bange, H. W. (2012). Sea-to-air and diapycnal nitrous oxide fluxes in the eastern tropical North Atlantic Ocean. Biogeosciences 9, 957-964. doi: 10.5194/bg-9-957-2012

Kurata, N., Vella, K., Hamilton, B., Shivji, M., Soloviev, A., Matt, S., et al. (2016). Surfactant-associated bacteria in the near-surface layer of the ocean. Sci. Rep. 6:19123. doi: 10.1038/srep19123

Kuznetsova, M., and Lee, C. (2001). Enhanced extracellular enzymatic peptide hydrolysis in the sea-surface microlayer. Mar. Chem. 73, 319-332. doi: $10.1016 / \mathrm{S} 0304-4203(00) 00116-\mathrm{X}$

Kuznetsova, M., and Lee, C. (2002). Dissolved free and combined amino acids in nearshore seawater, sea surface microlayers and foams: Influence of extracellular hydrolysis. Aquat. Sci. 64, 252-268. doi: 10.1007/s00027-0028070-0

Kuznetsova, M., Lee, C., and Aller, J. (2004).Enrichment of amino acids in the sea surface microlayer at coastal and open ocean sites in the North Atlantic Ocean. Limnol. Oceanogr. 49, 1605-1619. doi: 10.4319/lo.2004.49.5.1605

Laß, K., and Friedrichs, G. (2011). Revealing structural properties of the marine nanolayer from vibrational sum frequency generation spectra. J. Geophys. Res. 116, 1-15. doi: 10.1029/2010JC006609

Laß, K., Bange, H., and Friedrichs, G. (2013). Seasonal signatures in SFG vibrational spectra of the sea surface nanolayer at boknis eck time series station (SW Baltic Sea). Biogeosciences 10, 5325-5334. doi: 10.5194/bg-10-5325-2013

Laß, K., Kleber, J., and Friedrichs, G. (2010). Vibrational sum-frequency generation as a probe for composition, chemical reactivity, and film formation dynamics of the sea surface nanolayer. Limnol. Oceanogr. Methods 8, 216-228. doi: 10.4319/lom.2010.8.216

Law, C. S., Breviere, E., de Leeuw, G., Garcon, V., Guieu, C., Kieber, D. J., et al. (2013). Evolving research directions in surface ocean-lower atmosphere (SOLAS) science. Environ. Chem. 10, 1-16. doi: 10.1071/EN12159

Leck, C., and Bigg, E. K. (2005a). Biogenic particles in the surface microlayer and overlaying atmosphere in the central Arctic ocean during summer. Tellus 57B, 305-316. doi: 10.3402/tellusb.v57i4.16546

Leck, C., and Bigg, E. K. (2005b). Source and evolution of marine aerosol-a new perspective. Geophys. Res. Lett. 32, 1-4. doi: 10.1029/2005GL023651

Lewis, E. R., and Schwartz, S. E. (2004). Front Matter, in Sea Salt Aerosol Production: Mechanisms, Methods, Measurements and Models - A Critical Review. Washington, DC: American Geophysical Union. doi: 10.1002/9781118666050.fmatter

Liang, J. H., Deutsch, C., McWilliams, J. C., Baschek, B., Sullivan, P. P., and Chiba, D. (2013). Parameterizing bubble-mediated air-sea gas exchange and its effect on ocean ventilation. Global Biogeochem. Cycles 27, 894-905. doi: $10.1002 / g b c .20080$

Lin, I. I., Wen, L. S., Liu, K.-K., Tsai, W.-T., and Liu, A. K. (2002). Evidence and quantification of the correlation between radar backscatter and ocean colour supported by simultaneously acquired in situ sea truth. Geophys. Res. Lett. 29, 1464. doi: 10.1029/2001GL014039

Liss, P. S., and Duce, R. A. (2005). The Sea Surface and Global Change. New York, NY: Cambridge University Press.

Liss, P. S., and Merlivat, L. (1986). "Air-sea gas exchange rates: introduction and synthesis," in The Role of Air-Sea Exchange in Geochemical Cycling, ed P. Buat-Ménard (Dordrecht: Springer Netherlands), 113-127.

Liss, P. S., and Slater, P. G. (1974). Flux of gases across the air-sea interface. Nature 247, 181-184.

Liss, P. S., Marandino, C. A., Dahl, E. E., Helmig, D., and Hintsa, E. J. (2014). "Short-lived trace gases in the surface ocean and atmosphere," in OceanAtmosphere Interactions of Gases and Particles, eds P.S. Liss and M.T. Johnson (Heidelberg: Springer), 1-54.

Liu, A. K., Yu, S. Y., Tseng, W. Y., and Pichel, W. G. (2000). Wavelet analysis of SAR images for coastal monitoring. Can. J. Remote Sens. 26, 494-50. doi: $10.1080 / 07038992.2000 .10874790$

Long, R. A., and Azam, F. (1996). Abundant protein-containing particles in the sea. Aquat. Microb. Ecol. 10, 213-221.

McCoy, D. T., Burrows, S. M., Wood, R., Grosvenor, D. P., Elliott, S. M., Ma, P. L., et al. (2015). Natural aerosols explain seasonal and spatial patterns of Southern Ocean cloud albedo. Sci. Adv. 1:e1500157. doi: 10.1126/sciadv.1500157 
McCready, M. J., Vassiliadou, E., and Hanratty, T. J. (1986). Computer simulation of turbulent mass transfer at a mobile interface. AIChE J. 32, 1108-1115.

McKenna, S. P., and McGillis, W. R. (2004). The role of free-surface turbulence and surfactants in air-water gas transfer. Int. J. Heat Mass Transf. 47, 539-553. doi: 10.1016/j.ijheatmasstransfer.2003.06.001

Mesarchaki, E., Kräuter, C., Krall, K. E., Bopp, M., Helleis, F., Williams, J., et al. (2015). Measuring air-sea gas-exchange velocities in a large-scale annular wind-wave tank. Ocean Sci. 11, 121-138. doi: 10.5194/os-11-121-2015

Modini, R. L., Russell, L. M., Deane, G. B., and Stokes, M. D. (2013). Effect of soluble surfactant on bubble persistence and bubble-produced aerosol particles. J. Geophys. Res. Atmos. 118, 1388-1400. doi: 10.1002/jgrd.50186

Nakajima, R., Tsuchiya, K., Nakatomi, N., Yoshida, T., Tada, Y., Konno, F., et al. (2013). Enrichment of microbial abundance in the sea-surface microlayer over a coral reef: implications for biogeochemical cycles in reef ecosystems. Mar. Ecol. Prog. Ser. 490, 11-22. doi: 10.3354/meps10481

Navakov, T., and Penner, J. E. (1993). Large contribution of organic aerosols to cloud-condensation-nuclei concentrations. Nature 365, 823-826.

Nightingale, P. D., Malin, G., Law, C. S., Watson, A. J., Liss, P. S., Liddicoat, M. I., et al. (2000). In situ evaluation of air-sea gas exchange parameterizations using novel conservative and volatile tracers. Global Biogeochem. Cycles 14, 373-387. doi: 10.1029/1999GB900091

O’Dowd, C. D., Facchini, M. C., Cavalli, F., Ceburnis, D., Mircea, M., Decesari, S., et al. (2004). Biogenically driven organic contribution to marine aerosol. Nature 431, 676-680. doi: 10.1038/nature02959

O’Dowd, C., Ceburnis, D., Ovadnevaite, J., Bialek, J., Stengel, D B., Zacharias, M., et al. (2015). Connecting marine productivity to sea-spray via nanoscale biological processes: phytoplankton dance or death disco? Sci. Rep. 5:14883. doi: $10.1038 /$ srep 14883

Obernosterer, I., Catala, P., Lami, R., Caparros, J., Ras, J., Bricaud, A., et al. (2008). Biochemical characteristics and bacterial community structure of the sea surface microlayer in the South Pacific Ocean. Biogeosciences 5, 693-705. doi: 10.5194/bg-5-693-2008

Orellana, M. V., Matrai, P. A., Leck, C., Rauschenberg, C. D., Lee, A. M., and Coz, E. (2011). Marine microgels as a source of cloud condensation nuclei in the high Arctic. Proc. Natl. Acad. Sci. U.S.A. 108, 13612-13617. doi: 10.1073/pnas. 1102457108

Ortega-Retuerta, E. U., Passow, U., Duarte, C. M., and Reche, I. (2009). Effects of ultraviolet B radiation on (not so) transparent exopolymer particles. Biogeosciences 6, 3071-3080. doi: 10.5194/bg-6-3071-2009

Ovadnevaite, J., Manders, A., de Leeuw, G., Ceburnis, D., Monahan, C., Partanen., A. I., et al. (2014). A sea spray aerosol flux parameterization encapsulating wave state. Atmos. Chem. Phys. 14, 1837-1852. doi: 10.5194/acp-14-1837-2014

Passow, U. (2002). Transparent exopolymer particles (TEP) in aquatic environments. Prog. Oceanogr. 55, 287-333.doi: 10.1021/es5041738

Passow, U., and Alldredge, A. L. (1999). Do transparent exopolymer particles (TEP) inhibit grazing by the euphausiid Euphausia pacifica? J. Plankton Res. $21,2203-2217$

Pereira, R., Schneider-Zapp, K., and Upstill-Goddard, R. C. (2016). Surfactant control of gas transfer velocity along an offshore coastal transect: results from a laboratory gas exchange tank. Biogeosciences 13, 3981-3989. doi: 10.5194/bg-13-3981-2016

Pogorzelski, S. J., Kogut, A. D., and Mazurek, A. Z. (2006). Surface rheology parameters of source-specific surfactant films as indicators of organic matter dynamics. Hydrobiologia 55, 67-81. doi: 10.1007/s10750-005-1007-6

Prather, K., Bertram, T. H., Grassian, V. H., Deane, G. B., Stokes, M. D., DeMott, P. J.,et al. (2013). Bringing the ocean into the laboratory to probe the chemical complexity of sea spray aerosol. Proc. Natl. Acad. Sci. U.S.A. 110, 7550-7555. doi: 10.1073/pnas.1300262110

Quinn, P. K., and Bates, T. S. (2011). The case against climate regulation via oceanic phytoplankton sulphur emissions. Nature 480, 51-56. doi: $10.1038 /$ nature 10580

Quinn, P. K., Collins, D. B., Grassian, V. H., Prather, K. A., and Bates, T. S. (2015). Chemistry and related properties of freshly emitted sea spray aerosol. Chem. Rev. 115, 4383-4399. doi: 10.1021/cr500713g

Quinn, P. K., Bates, T. S., Schulz, K. S., Coffman, D. J., Frossard, A. A., Russell, L. M., et al. (2014). Contribution of sea surface carbon pool to organic matter enrichment in sea spray aerosol. Nat. Geosci. 7, 228-232. doi: 10.1038/ ngeo2092
Reinthaler, T., Sintes, E., and Herndl, G. J. (2008). Dissolved organic matter and bacterial production and respiration in the sea-surface microlayer of the open Atlantic and the western Mediterranean sea. Limnol. Oceanogr. 53, 122-136. doi: 10.4319/lo.2008.53.1.0122

Resch, F. (1986). "Oceanic air bubbles as generators of marine aerosols," in Oceanic Whitecaps, eds E. C. Monahan and G. Mac Niocaill (Springer Netherlands), 101-112.

Russell, L. M., Hawkins, L. N., Frossard, A. A., Quinn, P. K., and Bates, T. S. (2010). Carbohydrate-like composition of submicron atmospheric particles and their production from ocean bubble bursting. Proc. Natl. Acad. Sci. U.S.A. 107, 6652-6657. doi: 10.1073/pnas.0908905107

Sabbaghzadeh, B., Upstill-Goddard, R. C., Beale, R., Pereira, R., and Nightingale, P. D. (2017). The Atlantic Ocean surface microlayer from $50^{\circ} \mathrm{N}$ to $50^{\circ} \mathrm{S}$ is ubiquitously enriched in surfactants at wind speeds up to $13 \mathrm{~m} \mathrm{~s}^{-1}$. Geophys. Res. Lett. 44, 2852-2858. doi: 10.1002/2017GL072988

Salter, M. E., Zieger, P., Acosta Navarro, J. C., Grythe, H., Kirkevåg, A., Rosati, B., et al. (2015). An empirically derived inorganic sea spray source function incorporating sea surface temperature. Atmos. Chem. Phys. 15, 11047-11066. doi: 10.5194/acp-15-11047-2015

Salter, M. E., Upstill-Goddard, R. C., Nightingale, P. D., Archer, S. D., Blomquist, B., Ho, D. T., et al. (2011). Impact of an artificial surfactant release on air-sea gas fluxes during Deep Ocean Gas Exchange Experiment II. J. Geophys. Res. 116, C11016. doi: 10.1029/2011JC007023 2011

Santos, A. L., Oliveira, V., Baptista, I., Henriques, I., Gomes, N. C. M., Almeida, A., et al. (2012). Effects of UV-B radiation on the structural and physiological diversity of bacterioneuston and bacterioplankton. Appl. Environ. Microbiol. 78, 2066. doi: 10.1128/AEM.06344-11

Schimpf, U., Garbe, C., and Jähne, B. (2004). Investigation of transport processes across the sea surface microlayer by infrared imagery. J. Geophys. Res. Oceans 109, 1-14. doi: 10.1029/2003JC001803

Schmidt, R., and Schneider, B. (2011). The effect of surface films on the air-sea gas exchange in the Baltic Sea. Mar. Chem. 126, 56-62. doi: 10.1016/j.marchem.2011.03.007

Schmitt-Kopplin, P., Liger-Belair, G., Koch, B. P., Flerus, R., Kattner, G., Harir, M., et al. (2012). Dissolved organic matter in sea spray: a transfer study from marine surface water to aerosols. Biogeosciences 9, 1571-1582. doi: 10.5194/bg-9-1571-2012

Schneider-Zapp, K., Salter, M. E., and Upstill-Goddard, R. C. (2014). An automated gas exchange tank for determining gas transfer velocities in natural seawater samples. Ocean Sci. 10, 587-600. doi: 10.5194/os-10-587-2014

Sharoni, S., Trainic, M., Schatz, D., Lehahn, Y., Flores, M. J., Bidle, K. D., et al. (2015). Infection of phytoplankton by aerosolized marine viruses. Proc. Natl. Acad. Sci.U.S.A. 112, 6643-6647. doi: 10.1073/pnas. 1423667112

Sieburth, J. M. (1983). "Microbiological and organic-chemical processes in the surface and mixed layers," in Air-Sea Exchange of Gases and Particles, eds P. S. Liss and W.G.N. Slinn (Hingham, MA: Reidel Publishers Co), 121-172.

Soloviev, A. V., and Schlüssel, P. (1994). Parameterization of the cool skin of the ocean and of the air-ocean gas transfer on the basis of modeling surface renewal. J. Phys. Oceanogr. 24, 1339-1346.

Springer, T. G., and Pigford, R. L. (1970). Influence of Surface Turbulence and Surfactants on Gas Transport through Liquid Interfaces. Ind. Eng. Chem. Fundam. 9, 458-465. doi: 10.1021/i160035a025

Stolle, C., Labrenz, M., Meeske, C., and Jürgens, K. (2011). The bacterioneuston community structure of the southern Baltic Sea and its dependence on meteorological conditions. Appl. Environ. Microbiol. 77, 3726-3733. doi: 10.1128/AEM.00042-11

Stolle, C., Nagel, K., Labrenz, M., and Jürgens, K. (2010). Succession of the sea-surface microlayer in the coastal Baltic Sea under natural and experimentally induced low-wind conditions. Biogeosciences 7, 2975-2988. doi: $10.5194 /$ bg-7-2975-2010

Taylor, J. D., and Cunliffe, M. (2014). High-throughput sequencing reveals neustonic and planktonic microbial eukaryote diversity in coastal waters. $J$. Phycol. 50, 960-965. doi: 10.1111/jpy.12228

Taylor, J. D., and Cunliffe, M. (2016). Multi-year assessment of coastal planktonic fungi reveals environmental drivers of diversity and abundance. ISME J. 10, 2118-2128. doi: 10.1038/ismej.2016.24

Taylor, J. D., Cottingham, S. D., Billinge, J., and Cunliffe, M. (2014). Seasonal microbial community dynamics correlate with phytoplankton-derived 
polysaccharides in surface coastal waters. ISME J. 8, 245-248. doi: 10.1038/ismej.2013.178

Thornton, D. C. O., Brooks, S. D., and Chen, J. (2016). Protein and carbohydrate exopolymer particles in the sea surface microlayer (SML). Front. Mar. Sci. 3:135. doi: 10.3389/fmars.2016.00135

Tinel, L., Rossignol, S., Bianco, A., Passananti ,M., Perrier, S., Wang, X., et al. (2016). Mechanistic Insights on the Photosensitized Chemistry of a Fatty Acid at the Air/Water Interface. Environ. Sci. Technol. 50, 11041-11048. doi: 10.1021/acs.est.6b03165

Tsai, W.-T. (1996). Impact of a surfactant on a turbulent shear layer under the air-sea interface. J. Geophys. Res. 101, 28557-28568.

Tsai, W.-T. (1998). A numerical study of the evolution and structure of a turbulent shear layer under a free surface. J. Fluid Mech. 354, 239-276.

Tsai, W.-T., and Liu, K.-K. (2003). An assessment of the effect of sea surface surfactant on global atmosphere-ocean CO2 flux. J. Geophys. Res. 108, 3127. doi: 10.1029/2000JC000740

Turney, D. E., and Banerjee, S. (2013). Air-water gas transfer and near-surface motions. J. Fluid Mech. 733, 588-624. doi: 10.1017/jfm.2013.435

Turney, D. E., Smith, W. C., and Banerjee, S. (2005). A measure of near-surface fluid motions that predicts air-water gas transfer in a wide range of conditions. Geophys. Res. Lett. 32, 1-4. doi: 10.1029/2004GL021671

Upstill-Goddard, R. C. (2006). Air-sea gas exchange in the coastal zone. Estuar. Coast. Shelf Sci. 70, 388-404. doi: 10.1016/j.ecss.2006.05.043

Upstill-Goddard, R. C., Frost, T., Henry, G. R., Franklin, M., Murrell, J. C., and Owens, N. J. P. (2003). Bacterioneuston control of air-water methane exchange determined with a laboratory gas exchange tank. Glob. Biogeochem. Cycles 17, 1108. doi: 10.1029/2003GB002043

van Pinxteren, M., and Herrmann, H. (2013). Glyoxal and methylglyoxal in atlantic seawater and marine aerosol particles: method development and first application during the polarstern cruise ANT XXVII/4. Atmos. Chem. Phys. 13, 11791-11802. doi: 10.5194/acp-13-11791-2013

van Pinxteren, M., Müller, C., Iinuma, Y., Stolle, C., and Herrmann, H. (2012). Chemical characterization of dissolved organic compounds from coastal sea surface microlayers (Baltic Sea, Germany). Environ. Sci. Technol. 46, 10455-10462. doi: 10.1021/es204492b

Wanninkhof, R. (1992). Relationship between wind speed and gas exchange. J. Geophys. Res. 97, 7373-7382.
Wanninkhof, R., Asher, W. E., Ho, D. T., Sweeney, C., and McGillis, W. R. (2009). Advances in quantifying air-sea gas exchange and environmental forcing. Annu. Rev. Mar. Sci. 1, 213-244. doi: 10.1146/annurev.marine.010908. 163742

Wilson, T. W., Ladino, L. A., Alpert, P. A., Breckels, M. N., Brooks, I. M., Browse, J., et al. (2015). A marine biogenic source of atmospheric ice nucleating particles. Nature 525, 234-238. doi: 10.1038/nature14986

Wolfe, G. V., and Steinke, M. (1996). Grazing-activated production of dimethyl sulfide (DMS) by two clones of Emiliania huxleyi, Limnol. Oceanogr. 41, $1151-1160$.

Woolf, D. K., Bowyer, P. A., and Monahan, E. C. (1987). Discriminating between the film drops and jet drops produced by a simulated whitecap. J. Geophys. Res. Oceans 92, 5142-5150.

Wurl, O., Stolle, C., Van Thuoc, C., The Thu, P., and Mari, X. (2016). Biofilm-like properties of the sea surface and predicted effects on airsea CO2 exchange. Prog. Oceanogr. 144, 15-24. doi: 10.1016/j.pocean.2016. 03.002

Wurl, O., Wurl, E., Miller, L., Johnson, K., and Vagle, S. (2011). Formation and global distribution of sea-surface microlayers. Biogeosciences 8, 121-135. doi: 10.5194/bg-8-121-2011

Yang, M., Beale, R., Liss, P., Johnson, M., Blomquist, B., and Nightingale, P. (2014). Air-sea fluxes of oxygenated volatile organic compounds across the Atlantic Ocean. Atmos. Chem. Phys. 14, 7499-7517. doi: 10.5194/acp-14-74 99-2014

Conflict of Interest Statement: The authors declare that the research was conducted in the absence of any commercial or financial relationships that could be construed as a potential conflict of interest.

Copyright (c) 2017 Engel, Bange, Cunliffe, Burrows, Friedrichs, Galgani, Herrmann, Hertkorn, Johnson, Liss, Quinn, Schartau, Soloviev, Stolle, Upstill-Goddard, van Pinxteren and Zäncker. This is an open-access article distributed under the terms of the Creative Commons Attribution License (CC BY). The use, distribution or reproduction in other forums is permitted, provided the original author(s) or licensor are credited and that the original publication in this journal is cited, in accordance with accepted academic practice. No use, distribution or reproduction is permitted which does not comply with these terms. 